Title Page

\author{
Original Article
}

Title: Preparedness, Perceived Impact and Concerns of health Care Workers in a Teaching Hospital during Coronavirus Disease (COVID-19).

Type of Article: Original Article

Number of Tables: 4

Figures: 0

References: 18

Authors:

1. Dr Kumar Saurabh

MBBS, MD

Assistant Professor, Department of Pediatrics, Government Medical College, Bettiah, Bihar, India.

Email id: dr saurabh life@yahoo.com

ORCID: 0000-0002-2347-5979

Phone: 7779931951

Contribution: concept, data analysis, drafting, literature review, critical revision, approval.

2. Dr Shilpi Ranjan

MBBS, MD

Assistant Professor, Department of Community Medicine, Nalanda Medical College and Hospital, Patna, Bihar, India.

Email id: shilpishrivastava@ymail.com

ORCID: $0000-0001-7463=4506$

Phone: 7070876141 
Contribution: concept, data analysis, drafting, literature review, critical revision, approval.

\author{
Conflict of interest: None
}

Funding: None

Acknowledgement: The authors would like to thank all healthcare workers who participated in our study and for being as frontline warrior against Covid-19.

Ethical Approval: The study was approved by Institutional ethics committee.

Consent: Written informed consent was taken from participants.

Word count: 2004

\title{
Preparedness, Perceived Impact and Concerns of health Care Workers in a Teaching Hospital during Coronavirus Disease 2019 (COVID-19)
}

\begin{abstract}
:
Objective: Coronavirus Disease 2019 is a new threat to human lives worldwide. Preparedness of institutions during epidemic outbreak has a pivotal role in saving lives and preventing further spread. At the same time, these pandemics impact badly on professional and personal life of Health care workers. The objective of this study is to find the opinion of Health care workers regarding their level of preparedness, concerns and perceived impact related to this pandemic outbreak. Materials and Methods: in this study, random samples of doctors and nurses was provided with a selfadministered questionnaire regarding their preparedness, work and non-work related concerns and impact on their lives during Covid-19 outbreak. Results: Most of the Health Care Workers believed that their institute preparation to fight Covid-19 pandemic is better than prior to onset of this crisis ( $p$ 20.001). Work related stress was seen more commonly in nurses whereas higher frequency of non-work related stress was observed among doctors. Nurses (75.55\%) faith in their employer was more than doctors faith $(46.66 \%)$ regarding their medical needs. There was more acceptance of hydroxychloroquine as a prophylactic drug for Covid-19 in doctors compared to nurses ( $p$ [0.01). Conclusions: Though this institute was more prepared at the time of pandemic spread, substantial opportunity of improvement remains. The consistency of work and non work related anxiety and stress in health care workers is very high in present study group. Concerns and risks of Health Care Workers should be addressed ethically and adequately by strengthening safety measures and building trust in the system they work.
\end{abstract}

Keywords: COVID-19; HCW; Pandemic; Preparedness; Anxiety; Stress; Hydroxychloroquine 
medRxiv preprint doi: https://doi.org/10.1101/2020.07.15.20140095; this version posted July 17, 2020. The copyright holder for this preprint (which was not certified by peer review) is the author/funder, who has granted medRxiv a license to display the preprint in perpetuity. It is made available under a CC-BY-NC-ND 4.0 International license .

Introduction: In December 2019, a series of pneumonia cases of unknown origin were identified in Wuhan, the capital city of Hubei province, China with features similar to viral pneumonia ${ }^{[1]}$. The pathogen has been identified as a novel enveloped RNA beta coronavirus. The World Health Organisation (WHO) officially named the disease as coronavirus disease 2019 (COVID-19) and the pathogen as severe acute respiratory syndrome coronavirus 2 (SARS-Cov-2) on $11^{\text {th }}$ February $2020^{[2]}$. Person to person transmission has been documented as patients with the infection have been identified both in hospitals and in family settings ${ }^{[3],[4]}$

The World Health Organisation (WHO) declares Coronavirus disease 2019 (COVID-19) as a pandemic on $11^{\text {th }}$ March $2020^{[5]}$. As on 18 April 2020, globally laboratory confirmed cases were 2160207 with 146088 deaths $^{[6]}$. As per government of India record 13295 active cases of Covid-19 including Health Care Workers (HCW) were identified in India with 519 deaths and 2301 patients cured $^{[7]}$. Most of the worst affected countries including India started complete lockdown of nation on $25^{\text {th }}$ March $2020^{[8]}$.

The ability to respond quickly in the face of an emerging novel coronavirus disease 2019 is critical for safety of patients and their near ones. At this point of time, the capacity to work together across institutions and countries has proved most important step in the control of recent pandemics such as COVID-19. Indeed, these situations provide an opportunity to help in policy making in real time. $[9],[10]$

Health Care Workers (HCW) are at higher risk themselves of contracting COVID-19, and thus they can place their patients at risk. In China, more than $3300 \mathrm{HCW}$ have been infected and at least 22 had died. In Italy, almost $20 \%$ of HCW involved in COVID-19 treatment were infected, and some have died. ${ }^{[11]}$ Remember, unlike ventilators or wards HCW cannot be urgently manufactured or run at $100 \%$ occupancy for long periods. In this context government should treat HCW as human individuals and not simply as pawns to be deployed.

We therefore investigate the preparedness, concerns and perceived impacts of doctors and nurses (HCW) at a medical college of north India.

\section{Materials \&Methods:}

A random sample of doctors and nurses of Government Medical College, Bettiah, India was invited to participate in the study during initial days of disease outbreak in India (From 1 March to 31 March2020). The admission of first batch of medical students to this institute was started in 2013. This is a tertiary care teaching hospital which could serve over four million populations. At this point of time two hundred bed corona isolation wards has been created so that patients with this disease could seek medical care.

Study was approved by institutional ethics committee. Written informed consent was taken from every participant after explaining them objective of the study. All participants were provided with a preformed self-administered questionnaire which includes different sections in order to investigate their demographic data, education, years of experiences, PPE training, preparedness, concerns and perceived impact. Our questionnaire was adopted from a previous study of Singapore and Egypt ${ }^{[12,13]}$. Sections were as follows.

1. Demographic data.

2. Preparedness of doctors and nurses for Covid-19 pandemic. 
3. Work related concerns during Covid-19 pandemic.

4. Non-work related concerns during Covid-19.

5. Perceived impacts of HCWs.

In statistical methods, first descriptive analysis was done which includes frequency, percent, mean, standard deviation. Pearson's Chi square test for categorical variables was used to compare doctors and nurses. Level of significance was set at $p$ ? 0.05. Data entry and statistical analysis were performed using the Statistical Package for Social Science (SPSS) version 26.0.

Results:

Table 1. Preparedness of Health Care Workers for Covid-19 pandemic

\begin{tabular}{|l|l|l|l|}
\hline Preparedness for Covid-19 Pandemic & $\begin{array}{l}\text { Doctors } \\
\mathbf{N}=75(\%)\end{array}$ & $\begin{array}{l}\text { Nurses } \\
\mathbf{N}=45(\%)\end{array}$ & $\boldsymbol{P}$ value \\
\hline Covid-19 is a an important health problem. & $74(98.66)$ & $42(93.33)$ & 0.11 \\
\hline $\begin{array}{l}\text { Covid-19 is more important than the other } \\
\text { infection control-related problems that I deal } \\
\text { with on a regular basis. }\end{array}$ & $56(74.66)$ & $40(88.88)$ & 0.06 \\
\hline $\begin{array}{l}\text { Prior to Covid-19 emergence, locally endemic } \\
\text { diseases were viewed as an important health } \\
\text { problem at my institution. }\end{array}$ & $39(52.00)$ & $24(54.33)$ & 0.88 \\
\hline $\begin{array}{l}\text { Senior-level hospital administrators believed } \\
\text { that Covid-19 was a more important problem } \\
\text { than I thought it was. }\end{array}$ & $63(84.00)$ & $39(86.66)$ & 0.69 \\
\hline $\begin{array}{l}\text { Prior to the current Covid-19 crisis, my } \\
\text { hospital was well prepared for a potentially } \\
\text { pandemic situation such as Covid-19. }\end{array}$ & $14(18.66)$ & $8(17.77)$ & 0.90 \\
\hline $\begin{array}{l}\text { At this point in time, my hospital is well } \\
\text { prepared for a potentially pandemic situation } \\
\text { such as Covid-19. }\end{array}$ & $28(37.33)$ & $27(60.00)$ & 0.015 \\
\hline $\begin{array}{l}\text { During the Covid-19 crisis, adequate } \\
\text { resources to respond to the crisis were } \\
\text { provided. }\end{array}$ & $27(36.00)$ & $11(24.44)$ & 0.18 \\
\hline $\begin{array}{l}\text { During the Covid-19 crisis, other important } \\
\text { infection prevention-related activities were } \\
\text { neglected. }\end{array}$ & $42(56.00)$ & $18(40.00)$ & 0.08 \\
\hline $\begin{array}{l}\text { N-95 masks have been readily available } \\
\text { throughout the Covid-19 crisis at my } \\
\text { institution. }\end{array}$ & $5(6.66)$ & $3(6.66)$ & 1.0 \\
\hline $\begin{array}{l}\text { The recommendation for airborne } \\
\text { precautions for suspected Covid-19 cases was } \\
\text { appropriate at the beginning of the Covid-19 }\end{array}$ & $28(37.33)$ & $17(37.77)$ & 0.96 \\
\hline
\end{tabular}




\begin{tabular}{|l|l|l|l|}
\hline crisis at my institution. & & & \\
\hline $\begin{array}{l}\text { Surgical masks have been readily available } \\
\text { throughout the Covid-19 crisis at my } \\
\text { institution. }\end{array}$ & $7(9.33)$ & $4(8.88)$ & 0.93 \\
\hline $\begin{array}{l}\text { Alcohol based hand hygiene products have } \\
\text { been readily available throughout the Covid- } \\
19 \text { crisis at my institution. }\end{array}$ & $9(12.00)$ & $3(6.66)$ & 0.34 \\
\hline $\begin{array}{l}\text { All healthcare workers should be mandated to } \\
\text { receive the prophylactic dose of } \\
\text { Hydroxychloroquine. }\end{array}$ & $56(74.66)$ & $23(51.11)$ & 0.008 \\
\hline
\end{tabular}

Table 2: Work related concerns of Health Professional due to Covid-19

\begin{tabular}{|l|l|l|l|}
\hline $\begin{array}{l}\text { Work related concerns } \\
\text { Of Health Professional }\end{array}$ & $\begin{array}{l}\text { Doctors } \\
\mathbf{N}=\mathbf{7 5}(\%)\end{array}$ & $\begin{array}{l}\text { Nurses } \\
\mathbf{N}=\mathbf{4 5}(\%)\end{array}$ & $\boldsymbol{P}$ value \\
\hline $\begin{array}{l}\text { My job would put me at } \\
\text { great risk of exposure to } \\
\text { Covid-19 }\end{array}$ & $71(94.66)$ & $44(97.77)$ & 0.39 \\
\hline $\begin{array}{l}\text { I am afraid of falling ill } \\
\text { with covid-19 }\end{array}$ & $66(88.00)$ & $36(80.00)$ & 0.23 \\
\hline $\begin{array}{l}\text { I feel that I should not } \\
\text { be looking after patients } \\
\text { with Covid-19 }\end{array}$ & $21(28.00)$ & $18(40.00)$ & 0.17 \\
\hline $\begin{array}{l}\text { I would accept that the } \\
\text { risk of contracting } \\
\text { Covid-19 is part of my } \\
\text { job }\end{array}$ & $49(65.33)$ & $40(88.88)$ & 0.0043 \\
\hline $\begin{array}{l}\text { I might look for another } \\
\text { job or consider resigning } \\
\text { because of the risk of } \\
\text { contracting Covid-19 }\end{array}$ & $6(8.00)$ & $5(11.11)$ & 0.56 \\
\hline $\begin{array}{l}\text { I would consider it } \\
\text { acceptable if my } \\
\text { colleagues resign } \\
\text { because of their fear of } \\
\text { Covid-19 }\end{array}$ & $7(9.33)$ & $6(13.33)$ & 0.49 \\
\hline $\begin{array}{l}\text { I am confident that my } \\
\text { employer would look } \\
\text { after my medical needs } \\
\text { if I were to fall ill with }\end{array}$ & $35(46.66)$ & $34(75.55)$ & 0.0019 \\
\hline
\end{tabular}


Table 3: Non-work related concerns of Health Professional due to Covid-19

\begin{tabular}{|l|l|l|l|}
\hline $\begin{array}{l}\text { Non-work related concerns } \\
\text { of Health Professional }\end{array}$ & $\begin{array}{l}\text { Doctors } \\
\mathbf{N}=\mathbf{7 5}(\%)\end{array}$ & $\begin{array}{l}\text { Nurses } \\
\mathbf{N}=45(\%)\end{array}$ & P value \\
\hline $\begin{array}{l}\text { people close to me would be } \\
\text { at high risk of getting Covid- } \\
19 \text { because of my job }\end{array}$ & $69(92.00)$ & $29(64.44)$ & 0.00016 \\
\hline $\begin{array}{l}\text { I would be concerned of my } \\
\text { family. }\end{array}$ & $70(93.33)$ & $41(91.11)$ & 0.65 \\
\hline $\begin{array}{l}\text { I would be concerned of my } \\
\text { friends. }\end{array}$ & $66(88.00)$ & $40(88.88)$ & 0.88 \\
\hline $\begin{array}{l}\text { I would be concerned of my } \\
\text { colleagues. }\end{array}$ & $66(88.00)$ & $41(91.11)$ & 0.59 \\
\hline $\begin{array}{l}\text { people close to me would be } \\
\text { worried for my health }\end{array}$ & $70(93.33)$ & $37(82.22)$ & 0.06 \\
\hline $\begin{array}{l}\text { people close to me would be } \\
\text { worried as they may get } \\
\text { infected by me. }\end{array}$ & $73(97.33)$ & $35(77.77)$ & 0.0005 \\
\hline
\end{tabular}

Table 4: Perceived impact on personal life and work of Health Professional due to Covid-19

\begin{tabular}{|l|l|l|l|}
\hline $\begin{array}{l}\text { Perceived impact on } \\
\text { personal life and work of } \\
\text { Health Professional }\end{array}$ & $\begin{array}{l}\text { Doctors } \\
\mathbf{N}=75(\%)\end{array}$ & $\begin{array}{l}\text { Nurses } \\
\mathbf{N}=(\%)\end{array}$ & P value \\
\hline $\begin{array}{l}\text { I would be afraid of telling } \\
\text { my family about the risk I } \\
\text { am exposed to }\end{array}$ & $42(56.00)$ & $28(62.22)$ & 0.50 \\
\hline $\begin{array}{l}\text { people would avoid me } \\
\text { because of my job }\end{array}$ & $33(44.00)$ & $26(57.77)$ & 0.14 \\
\hline $\begin{array}{l}\text { people would avoid my } \\
\text { family members because of } \\
\text { my job }\end{array}$ & $39(52.00)$ & $24(53.33)$ & 0.88 \\
\hline $\begin{array}{l}\text { I would avoid telling other } \\
\text { people about the nature of } \\
\text { my job }\end{array}$ & $21(28.00)$ & $13(28.88)$ & 0.91 \\
\hline $\begin{array}{l}\text { there would be adequate } \\
\text { staff at my workplace to } \\
\text { handle the increased } \\
\text { demand }\end{array}$ & $36(48.00)$ & $18(40.00)$ & 0.39 \\
\hline $\begin{array}{l}\text { there would be more } \\
\text { conflict amongst colleagues }\end{array}$ & $56(74.66)$ & $26(57.77)$ & 0.54 \\
\hline
\end{tabular}




\begin{tabular}{|l|l|l|l|}
\hline at work & & & \\
\hline $\begin{array}{l}\text { I would feel more stressed } \\
\text { at work }\end{array}$ & $71(94.66)$ & $33(73.33)$ & 0.0008 \\
\hline $\begin{array}{l}\text { I would have an increase in } \\
\text { workload }\end{array}$ & $56(74.66)$ & $32(71.11)$ & 0.66 \\
\hline $\begin{array}{l}\text { I would have to work } \\
\text { overtime }\end{array}$ & $55(73.33)$ & $12(26.66)$ & 0.00001 \\
\hline $\begin{array}{l}\text { I would have to do work not } \\
\text { normally done by me }\end{array}$ & $71(94.66)$ & $16(35.55)$ & 0.00001 \\
\hline
\end{tabular}

There were 120 respondents ( 75 doctors and 45 nurses), in which 53 (44.11\%) were females. The age distribution of respondents was as follows: $20-29$ years, 16 (13.33\%); 30-39 years, 61 (50.83\%); 40-49 years, 32 (26.66\%); 50-59 years, 9 (7.5\%); 60-69 years, 2 (1.66\%). The participant doctors were consultants (10.66\%), Assistant Professor/Assistant consultants (36.00), rest were residents (53.33\%). Experience of respondents in the field of health care was as follows; ? 5 year, 13 (10.83\%); 5-10 years, 62 (51.66); 11-15 years, 27 (22.50); 115 years, 18 (15.00).

Most of the HCWs agree that their institute was not ready appropriately to respond to this crisis. As only $18.66 \%$ of doctors and $17.77 \%$ of nurses believed that their institute was ready prior to this pandemic. But in contrast, when asked about preparedness at this point, most of nurses $(60 \%)$ answered yes against $37.33 \%$ of doctors with a significant $p$-value of 0.015 . when we compared answers of all 120 respondents prior to and at real time in terms of preparedness, we found a statistically significant difference of p[0.001. It means this institute has done well in this available time frame of 'prior' and 'at this point' [Table 1]. Second important result of table 1 is acceptance of hydroxychloroquine as a prophylactic drug for Covid-19 in doctors compared to nurses ( $p$ ?0.01). One more point of relevance is that $56 \%$ of doctors and $40 \%$ of nurses noticed that during Covid- 19 crisis other infection prevention related activities were neglected.

Table 2 shows $88.88 \%$ nurses in comparison of $65.33 \%$ doctors agree that risk of contracting Covid-

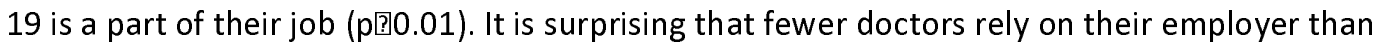
nurses when it comes to medical needs with a statistically significant difference ( $\mathrm{p}$ [0.01). It is good to find that most of the respondents either don't consider resigning or considering it acceptable for their colleagues.

There is higher non work related concerns in doctors than nurses. About $92 \%$ of doctors have higher worries of spreading infection to their families compared to $64.44 \%$ of nurses ( $p$ [20.01). Higher number of doctors (97.33\%) also believed that people close to them would be worried as they may get infected by them compared to nurses with a $p$ value of ?0.01 [Table 3].

This study also observes that Covid-19 has a higher impact on personal life and work of doctors than nurses [Table 4]. Doctors feel more stressed and assume that they would have to do work more and have to do the work not normally done by them (p?0.01).

\section{Discussion:}


medRxiv preprint doi: https://doi.org/10.1101/2020.07.15.20140095; this version posted July 17, 2020. The copyright holder for this preprint (which was not certified by peer review) is the author/funder, who has granted medRxiv a license to display the preprint in perpetuity. It is made available under a CC-BY-NC-ND 4.0 International license .

Adequacy and appropriateness of institutional preparedness and response to emergency situation like emerging and re-emerging pandemics is a key to safety of mankind. In this regard, response and experience from on-going crisis will be very helpful for future interventions. Result of this study provides a well oriented and timely perspective on the response to the current Covid-19 crisis. This tertiary care teaching institute plays a vital front line role in the management of a large population. Improvement in present scenario will be helpful in saving many lives. As per the mandate of reorientation of medical education scheme, this medical college is also linked to primary health facilities in rural and urban area. So primary care physicians will be also affected by the measures taken by this institute. ${ }^{[14]}$

In this study, we found that majority of HCW felt that their institute was not well prepared for COVID-19 crisis and was not provided with adequate resources. HCW did not receive any training regarding use of PPE (personal protection equipment) or any other infection control related training before the onset of this crisis. But with the progression of disease burden, many HCWs including doctors and nurses received training for PPE use through online courses conducted by government of India. Accessibility of HCWs to PPE, N-95 mask, surgical mask and alcohol based hand hygiene products in the events of pandemic is a critical component of preparedness plan. In this respect, it is very concerning that most doctors and nurses reported a shortage of these products. HCWs in the other parts of world are also working in the same scenario with inadequate resources. ${ }^{[11],[12]}$ world Health Organisation has also discussed this issue in a guideline stating that there is shortage of personal protective equipment in many parts of world which is endangering health workers lives. ${ }^{[15]}$

In view of severe acute respiratory syndrome and the threat of bioterrorism has lead to heroic efforts to address pandemic preparedness at health care institutions throughout the country. It is very much discouraging that the majority of respondents $64 \%$ doctors and $75.56 \%$ nurses believed that they do not have adequate resources to deal with Covid-19 pandemic. However many HCWs accept that, though their institution was not well prepare prior to the pandemic but with progression of pandemic, scenario improved and institute was in a better condition to tackle this acute crisis (p?0.001).

This medical college has faced its first pandemic and this Covid-19 crisis represents the first real test of preparedness. However, there is considerable opportunity for improvement remains as results of this study suggest. More effort is required to further refine and improve preparedness plans. We should plan to prepare in such a way that other vital health care activities and other infection control related activities should not be ignored during emergence of a new infection such as Covid-19 that may last for several months. Many of the participants of this study group (56\% doctors and $40 \%$ nurses) accepted that other infection control related activities were neglected during this period. One recent study from India also concluded that other vital health care activities like infection control, immunisation services and maternal care services were compromised due to COVID-19 pandemic. $^{[14]}$

Our results match with the outcome of previous study conducted in Germany and Egypt, where majority of $\mathrm{HCW}$ recognised the obligation to treat patients despite high risk. ${ }^{[13,16]}$ It is well known that during an outbreak, $\mathrm{HCW}$ are expected to work for longer period under high pressure and often with inadequate resources. At the same time they have to accept risks associated with close contact of severely ill patients. This necessarily increases their anxiety level and concerns. 
medRxiv preprint doi: https://doi.org/10.1101/2020.07.15.20140095; this version posted July 17, 2020. The copyright holder for this preprint (which was not certified by peer review) is the author/funder, who has granted medRxiv a license to display the preprint in perpetuity. It is made available under a CC-BY-NC-ND 4.0 International license .

Ministry of health and family welfare, has recommended chemoprophylaxis with hydroxychloroquine ( $400 \mathrm{mg}$ twice on day 1 , then $400 \mathrm{mg}$ once a week thereafter) for asymptomatic HCWs treating patients with suspected or confirmed Covid- 19 cases. ${ }^{[17]}$ Only $51 \%$ of nurses took the doses as compared to $74.66 \%$ of doctors. Prolongation of QT interval, its interaction with Azithromycin and glucose -6-phophate dehydrogenase deficiency were different concerns associated with this medicine in HCW. However, the use of hydroxychloroquine at large scale is of concern because the drug is untested, the benefits unknown and the risks not negligible. ${ }^{[18]}$

From our results it is clear that there are higher non work related stress and family stress among physician compared to nurses ${ }^{[13,16]}$. Result of this study coincides with previous studies. Around $50 \%$ of doctors and nurses admitted that people will avoid them and their family members because of nature of their job. Previous studies conducted at Singapore and Egypt show similar results $[12,13]$. Doctors were more worried than nurses about their stress level, overtime and extra workload.

This study highlights the contradiction between how HCW might feel about their professional duty for their patients and their personal duty to themselves and their families. Alongside concerns for their personal safety, HCW are anxious about passing infections to their families. ${ }^{[19]}$ The level of commitment of HCWs during a pandemic is potentially affected by these issues. This should be addressed in any national pandemic preparedness plan. ${ }^{[20]}$

Outbreaks like Covid-19 are critical reminders of the significance of public health readiness and the need for continued strengthening of public health agencies. This would be possible only by prior investments in public health preparedness. Moreover, problems associated with nationwide lockdown, migration of workers from big cities to their native place, psychological impact of quarantine, supply of daily needs like food and water, and financial support are other relevant points to be addressed for pandemic preparedness. ${ }^{[21]}$

Before reaching any conclusion based on this study, it is necessary to consider that this study had several potential limitations. Here, self-administered questionnaire was a method to investigate. Response rate is typically low in these types of questionnaire, also characteristics and view of other HCW is not known. Because of limited geographical limitations, study findings may not be generalised. But this study represents only a very few and early studies from India about the preparedness and concerns of HCW in response to COVID-19 pandemic.

In conclusion, this study provides an important insight into the concerns, perceived impact and preparedness of health care workers of an institute. Substantial revision of pandemic preparedness plans is required to improve the present scenario on the basis of current experience. To ensure effective functioning of an institute during public health emergencies government should considerably invest in infrastructure, capacity building and strengthening of health care services. The consistency of work and non work related anxiety and stress in health care workers is very high in present study group. So, professional ethical guidelines allowing for balancing the needs of society and personal risks are required to help HCW to fulfil their duties.

Acknowledgements: The authors would like to thank all healthcare workers who participated in our study and for being as frontline warrior against Covid-19. 
medRxiv preprint doi: https://doi.org/10.1101/2020.07.15.20140095; this version posted July 17, 2020. The copyright holder for this preprint (which was not certified by peer review) is the author/funder, who has granted medRxiv a license to display the preprint in perpetuity.

It is made available under a CC-BY-NC-ND 4.0 International license .

\section{References:}

1. Huang C, Wang Y, Li X, et al. Clinical features of patients infected with 2019 novel coronavirus in Wuhan, China. Lancet 2020; 395: 497-506.

2. Lu R, Zhao X, Li J, Niu P, Yang B, Wu H, et al. Genomic characterisation and epidemiology of 2019 novel coronavirus: implications for virus origins and receptor binding. Lancet. 2020;395(10224):565-74.

3. Guan W, Ni Z, HU Y, Liang W et al. Clinical characteristics of Coronavirus disease 2019 in China. N Eng J Med 2020 DOI: 10.1056/NEJMoa2002032

4. Chan JF, Yuan S, Kok KH, et al. A familial cluster of pneumonia associated with the 2019 novel coronavirus indicating person-to-person transmission: a study of a family cluster. Lancet 2020; 395: 514-23.

5. WHO. WHO Director General's. Available at:https://www.who.int/dg/speeches/detail/whodirector-general-s-opening-remarks-at-the-media-briefing-on-covid-19---11-march-2020. Accessed on 31 March 2020

6. World Health Organisation. Situation Reports. Available at: https://www.who.int/emergencies/diseases/novel-coronavirus-2019/situation-reports. Accessed on 19 April 2020

7. MOHFW. Government of India. Available at: https://www.mohfw.gov.in/. Accessed on 19 April 2020.

8. Wikipedia. India lockdown. Available at: https://en.wikipedia.org/wiki/2020 coronavirus lockdown in India. Accessed on 19 April 2020

9. Fineberg HV, Wilson ME. Epidemic science in real time. Science 2009;324:987.

10. Stein RA. Lessons from outbreaks of H1N1 influenza. Ann Intern Med 2009;151:59-62

11. Lo D. COVID-19: protecting health-care workers. The Lancet 2020; 395:922

12. Wong TY, Koh GCh, Cheong SK, et al. Concerns, perceived impact and preparedness in an avian influenza pandemic--a comparative study between healthcare workers in primary and tertiary care. Ann Acad Med Singapore 2008;37:96-102.

13. Gaafary MME, Elaziz KMA, Rahman AGA, Allam MF. Concerns, perceived impacts and preparedness of health care workers in a referral hospital in Egypt in facing influenza (H1N1) epidemic. J prev med hyg 2010; 51: 105-109.

14. Garg S, Basu S, Rustagi R, Borle A. Primary health care facility preparedness for outpatient service provision during the COVID-19 pandemic in India: Cross sectional study. JMIR Public Health and Survillence 2020; 6(2): e19927 https://doi.org/10.2196/19927

15. World Health Organization. Shortage of personal protective equipment endangering health workers worldwide. WHO, Geneva. 3 March 2020. Available at: https://www.who.int/newsroom/detail/03-03-2020-shortage-of-personal-protective-equipment-endangering-healthworkers-worldwide. Accessed 19 April 2020.

16. Ehrenstein BP, Hanses F, Salzberger B. Influenza pandemic and professional duty: family or patients first? A survey of hospital employees. BMC Public Health 2006;6:311.

17. MOHFW. Advisory on hydroxychloroquine. Available at: https://www.mohfw.gov.in/pdf/Advisoryontheuse ofHydroxychloroquinasprophylaxisforSAR SCoV2infection.pdf. Accessed on 31March2020. 
18. Rathi S, Ish P, Kalantri A, Kalantri S. Hydroxychloroquine prophylaxis for Covid-19 contacts in india. The Lancet ilnfectios Diseases 2020; Published online April 17, 2020 https://doi.org/10.1016/s1473-3099(20)30313-3

19. Sokol DK. Virulent epidemics and scope of healthcare workers' duty of care. Emerg Infect Dis 2006;12:1238-41.

20. Ruderman C, Tracy CS, Bensimon CM, Bernstein M, Hawryluck L, Shaul RZ, et al. On pandemics and the duty to care: whose duty? who cares? BMC Med Ethics 2006;7:E5.

21. Saurabh K, Ranjan S. Compliance and psychological impact of quarantine in children and adolescents due to Covid-19 pandemic. Indian J Pediatr (2020). https://doi.org/10.1007/s12098-020-03347-3 